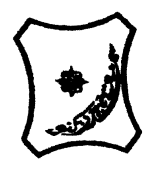

Bayero Journal of Pure and Applied Sciences, 12(1): 186 - 192

ISSN $2006-6996$

\title{
SPATIO-TEMPORAL DISTRIBUTION OF ZOOPLANKTON AND PHYSICO-CHEMICAL CONDITIONS OF WASAI RESERVIOR, KANO STATE, NIGERIA
}

\begin{abstract}
${ }^{1}$ Isyaku, I.H. and Ibrahim, S.
Department of Biological Sciences, Bayero University, Kano

Corresponding author: harunaisyaku1@gmail.com +2348066078258

\section{ABSTRACT}

A study of spatio-temporal distribution of zooplanktonic community in relation to physico-chemical water condition of WasaiReservoir was carried out between March and October, 2018. Three sampling sites selected for the purpose of this study were based on different human activities taking place in the areas like fishing, sand collection, washing etc. Nine physico-chemical and biological parameters were determined on fortnight basis 8:00 to 10:00am using standard methods. The result revealed that temperature, $\mathrm{pH}$, Electrical conductivity, Total dissolved solids, Dissolved oxygen, Biochemical oxygen demand, transparency, nitrate and phosphate ranged from 24.4 to $29.1^{\circ} \mathrm{C}, 6.4$ to 8.4 , 353.3 to $846.6 \mu \mathrm{S} / \mathrm{cm}, 264.3$ to $602.8 \mathrm{mg} / \mathrm{L}, 6.7$ to $10.9 \mathrm{mg} / \mathrm{L}, 2.8$ to6.8mg/L, 5.6 to $12.3 \mathrm{~cm}, 0.12$ to $0.55 \mathrm{mg} / \mathrm{L}$ and 0.08 to $0.22 \mathrm{mg} / \mathrm{L}$ respectively. A total of thirteen (13) species of zooplankton were identified from the reservoir out of which three (3) belong to the class copepoda with a highest mean value of 37.67 recorded in May and lowest, 8.88 in October. Five species belong to the class Rotifera with a highest mean of 2.93 recorded in March and lowest in June (0.80). Similarly five species belong to the class Cladocera, with highest mean of 3.40 in April and lowest (0.27) in June and October respectively. The result showed seasonal variation in zooplankton species, as thier distribution increased in the dry season than in wet season, primarily due to the increase in photic depth of the water. Pearson correlation coefficient was used to determine the relationship between zooplankton and physico-chemical parameters. The correlation coefficient of physico-chemical parameters and zooplankton of the reservoir revealed strong positive correlation between zooplankton, EC, TDS, pH, Temperature and transparency at $(P<0.05)$ while negative correlation exist between zooplankton, $B O D_{5,}$ DO, Nitrate and Phosphate at $(P<0.05)$.

Keywords: Distribution, Diversity, Reservoir, Wasai, Zooplankton.
\end{abstract}

\section{INTRODUCTION}

In a freshwater habitat, water quality provides substantial information about the existing resources which depends on the influence of physico-chemical parameters and biological features (Sivakumar and Karuppasamy, 2008). Ibrahim (2009) reported that abiotic environmental factors which include physical and chemical components have been reported in several studies to have a great influence on the well-being of aquatic organisms, plankton inclusive. Zooplanktons are microscopic organisms that are suspended in water. Zooplankton include many kinds of protozoa, microcrustaceans and other micro-invertebrates that are planktonic in water bodies (Omudu andOdeh, 2006). Zooplanktons are minute aquatic animals that are non-motile or very weak swimmers and they drift in water column of ocean, seas or freshwater bodies to move any great distance (Laws et al., 1988). Zooplankton play important role in food web by linking the primary producers (by consuming phytoplankton, mainly various bacteria and sometimes other zooplankton) and higher trophic levels. Zooplankton grazing on phytoplankton can transfer more than $50 \%$ of carbon fixed by primary production to higher trophic levels (Hart et al., 2000).The aim of the research was to carry out a spatio-temporal distribution of zooplanktonic community in relation to physico-chemical water condition of Wasai Reservoir. Wasai Reservior was constructed in 1976 and is situated in Minjibir Local Government Area (L.G.A) in North Eastern part of Kano metropolis, about $41.5 \mathrm{~km}$ from Kano city center (Duwa and Oyeyi, 2009). 


\section{MATERIALS AND METHODS Study Area}

Wasai Reservior was constructed in 1976 and is situated in Minjibir Local Government Area (L.G.A) in North Eastern part of Kano metropolis, about $41.5 \mathrm{~km}$ from Kano city center (Duwa and Oyeyi, 2009). The reservior was constructed for irrigation, recreation and wildlife conservation purposes. The reservoir was designed to contain 54.34 million cubic meters of water with surface area of $1,659 \mathrm{ha}$. The maximum depth of the reservoir is 14.3 meters(WRECA, 1974).

\section{Sampling sites}

Three (3) sampling sites (A, B and C) were selected for the purpose of this study. Site A: was located at Bela and it lies on latitude $12^{\circ} .103 \mathrm{~N}, 8^{\circ} .64 \mathrm{E}$. It's considered as inlet, where irrigation farming, fishing and human activities such as washing and sand collection are taking place with mean depth of $1.2 \mathrm{~m}$. Site B: This was considered as the midpoint of the water and located on $12^{\circ} .125 \mathrm{~N}, 8^{\circ} .67 \mathrm{E}$ and has a mean depth of $7.4 \mathrm{~m}$. Site C: It is on $12^{\circ} .138 \mathrm{~N}, 8^{\circ} .69 \mathrm{E}$. It is the outlet of the water and is located at Minjibir near Wasai village, where irrigation farming, fishing and other activities are taking place. The mean depth of the reservoir at this location is $2.3 \mathrm{~m}$ (Duwa and Oyeyi, 2009).

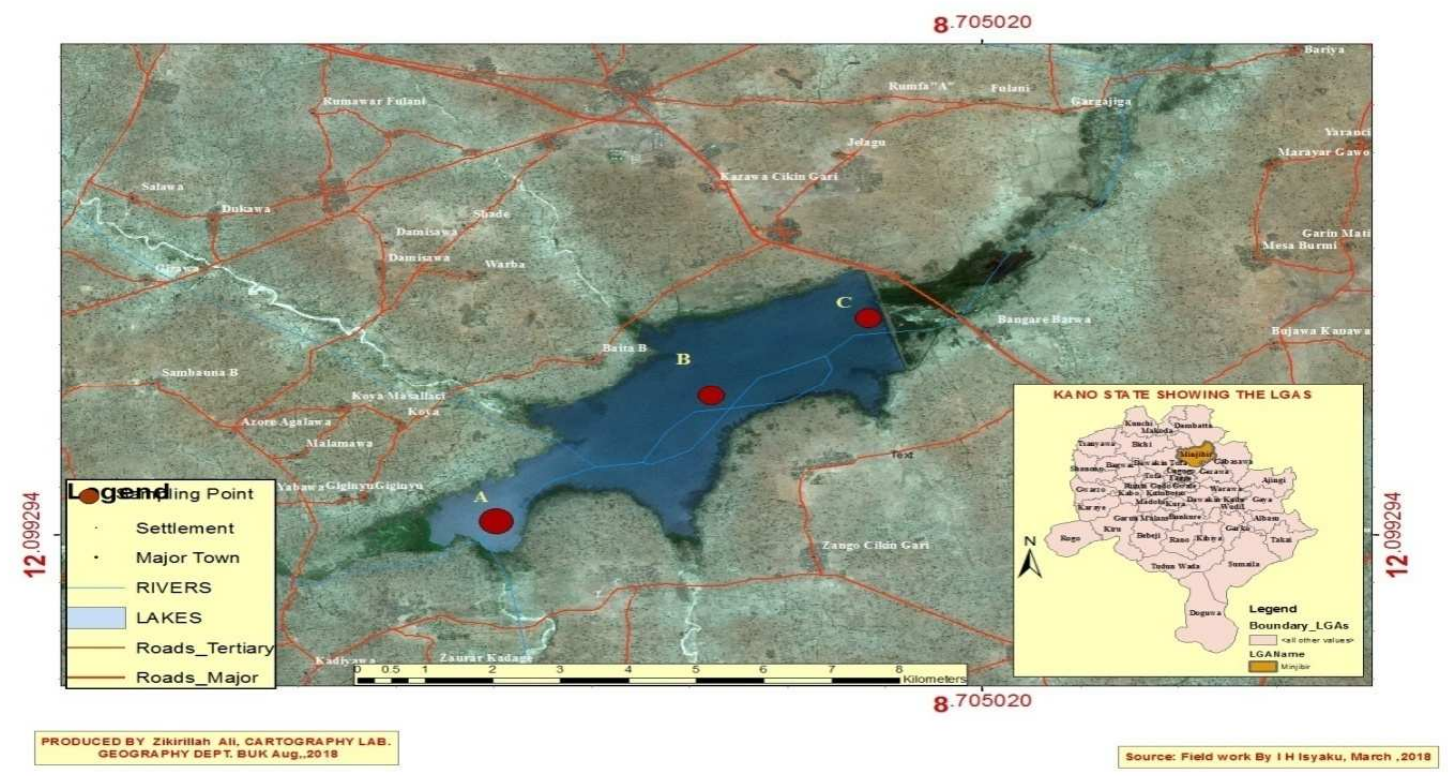

Figure 1: Map of Wasai Reservoir Showing Sampling Sites (Source: Catography lab., Bayero University Kano, 2018)

\section{Determination of Physico-Chemical Parameters}

Nine physico-chemical parameters were determined from the reservoir. Temperature, $\mathrm{pH}$, electrical conductivity (EC) and total dissolved solids (TDS) were determined in-situ using a digital $\mathrm{pH} / \mathrm{EC} / \mathrm{TDS} / \mathrm{Temperature}$ meter (HI9813-6 model, HANNA Instrument) as described by Mustapha (2009). Similarly, transparency was also measured in-situ; using a standard secchi disc as described by Brown (1987). Dissolved oxygen was measured at each site using Dissolved Oxygen meter (JPB-607A model) as described by the manufacturer. Biochemical oxygen demand $\left(\mathrm{BOD}_{5}\right)$ was determined according to technique used by Bennet and David (1974) and Bryan (1976). Nitrate-Nitrogen and Phosphate-Phosphorous were determined using nitrate test kit (ISO9001) and API phosphate test kit (API1595-01-0806, 1575-02-1504) as described in the manufacturer's manual.

\section{Zooplankton Collection and Preservation}

The zooplankton samples were collected using plankton net (30 microns mesh size) and $18 \mathrm{~cm}$ in

Diameter with a small plastic bottle container of $50 \mathrm{~cm}^{3}$ attached to its narrow end. The net was tied to a metal rod, towed horizontally for a fixed distance of 4meters and hauled out of the water. The water sample (containing the plankton) in the plastic bottle was emptied into another plastic bottle of $100 \mathrm{~cm}^{3}$ capacity (Hashemzadeh and Venkataramana, 2012). The container was always rinsed twice with distilled water in between the samples to avoid contamination as described by Ibrahim (2009). 
For preservation, $4 \%$ formalin was added to each of the samples. This solution was mixed by using the pasture pipette and the sample was kept for 24 hours undisturbed as described by Ibrahim (2009).

Identification and Counting of Zooplankton

The zooplankton was obtained by recording the number of the organisms per ml, Analysis of the zooplankton was done by putting one drop of fixed sample on a glass slide and then viewed under light microscope (magnification of $x 40$ and $x 100)$. The result obtained was recorded as the number of the organisms per $\mathrm{ml}$. The identification guides by Sandercock (1994), Sheil (1995) and Lynne (2004) were used to identify the different species of zooplankton in the samples.

Plankton abundance was estimated using the following relationship: -

$\mathrm{A}=\frac{Y Z}{a x}$
Where,

$\mathrm{A}=$ Average plankton per litre, $\mathrm{Y}=$ Average plankton per sample, $\mathrm{Z}=$ Concentrate volume $(\mathrm{ml})$

$a=$ original volume of sample per litre, $x=$ Volume of sample or counting chamber examined $(\mathrm{ml})$

\section{Statistical Analyses}

Two way Analysis of variance (ANOVA) was used to compare the relationship between physicochemical parameters and the biological data generated to ascertain whether there is significant difference or otherwise. However, Pearson correlation coefficient was used to ascertain the degree of linear relationship between zooplankton and physico-chemical parameters using $\mathrm{R}$ statistical package (version 3.4) (SAS, 1985).

\section{RESULTS}

The mean monthly values of surface water Temperature, $\mathrm{pH}$, electrical conductivity (EC) and total dissolved solids (TDS) throughout the study period are presented in Table 1 . The water temperature was found to be between $29.10 \pm 0.89^{\circ} \mathrm{C}$ and $24.42 \pm 0.19^{\circ} \mathrm{C}$, with the highest mean value recorded in the month of May and the lowest recorded in the month of September. The $\mathrm{pH}$ was highest $8.42 \pm 0.07$ in March and lowest $6.41 \pm 0.16$ in September. Electrical conductivity (EC) had its highest mean value of $846.67 \pm 11.55 \mu \mathrm{S} / \mathrm{cm}$ in April and lowest $353.33 \pm 15.28 \mu \mathrm{S} / \mathrm{cm}$ in August and October.The result revealed that total dissolved solids of the water were highest $602.80 \pm 8.945 \mathrm{mg} / \mathrm{L}$ in April and lowest $264.33 \pm 8.37 \mathrm{mg} / \mathrm{L}$ in August and October.

The monthly mean value of Dissolved oxygen, Biochemical oxygen demand, Transparency, Nitrate and Phosphate are presented in Table 2. DO range between $10.93 \pm 0.09 \mathrm{mg} / \mathrm{L}$ and $6.73 \pm 0.08 \mathrm{mg} / \mathrm{L}$, with the highest mean value recorded in August and lowest mean recorded in May. The ranged of $\mathrm{BOD}_{5}$ was $2.79 \pm 0.07 \mathrm{mg} /$ Lto6.79 $\pm 0.51 \mathrm{mg} / \mathrm{L}$; the lowest mean value was recorded in May and the highest recorded in August and September. Water transparency was highest in May with a mean value of $12.33 \pm 0.67 \mathrm{cmand}$ lowest in September $(5.55 \pm 0.18 \mathrm{~cm})$. The mean value of Nitrate concentration was highest $0.55 \pm 0.02 \mathrm{mg} / \mathrm{L}$ in August and October while lowest mean $0.12 \pm 0.04 \mathrm{mg} / \mathrm{L}$ was recorded in March respectively. Lastly, the mean value of phosphate obtained was $0.22 \pm 0.03 \mathrm{mg} / \mathrm{L}$ and $0.07 \pm 0.01 \mathrm{mg} / \mathrm{L}$ with a highest value in the month of September and lowest in the month of March respectively.

Table 2: Revealed the Pearson correlation coefficient between zooplankton and physicochemical parameters of Wasai Reservoir during the period of March to October 2018. The result revealed strong positive correlation between zooplankton, EC, TDS, pH, Temperature and transparency. While negative correlations exist between zooplankton, $\mathrm{BOD}_{5}, \mathrm{DO}$, Nitrate and Phosphate. 
Table 1: Mean Monthly Values of Physico-chemical Parameters of Wasai Reservoir Between March and October, 2018

\begin{tabular}{|c|c|c|c|c|c|c|c|c|c|}
\hline MONTH & $\begin{array}{l}\text { Temp. } \\
\left({ }^{\circ} \mathrm{C}\right)\end{array}$ & pH & $E C(\mu S / \mathrm{cm})$ & TDS (mg/L) & $\begin{array}{c}\text { DO } \\
(\mathrm{mg} / \mathrm{L})\end{array}$ & $\begin{array}{c}\mathrm{BOD}_{5} \\
(\mathrm{Mg} / \mathrm{L})\end{array}$ & $\begin{array}{c}\text { Transparency } \\
(\mathbf{c m})\end{array}$ & $\begin{array}{l}\text { Nitrate } \\
\text { (mg/L) }\end{array}$ & $\begin{array}{l}\text { Phosphate, } \\
\text { (mg/L) }\end{array}$ \\
\hline MARCH & $28.25 \pm 0.8$ & $8.423 \pm 0.1$ & $841.00 \pm 28.5$ & $584.64 \pm 10.02$ & $8.49 \pm 0.2$ & $4.04 \pm 0.41$ & $9.63 \pm 0.42$ & $0.12 \pm 0.04$ & $0.08 \pm 0.02$ \\
\hline APRIL & $27.70 \pm 1.0$ & $8.133 \pm 0.3$ & $846.67 \pm 11.5$ & $602.80 \pm 8.95$ & $7.10 \pm 0.4$ & $3.11 \pm 0.11$ & $10.00 \pm 0.56$ & $0.17 \pm 0.04$ & $0.08 \pm 0.01$ \\
\hline MAY & $29.10 \pm 0.9$ & $7.967 \pm 0.1$ & $800.00 \pm 43.6$ & $590.70 \pm 21.38$ & $6.73 \pm 0.1$ & $2.79 \pm 0.07$ & $12.33 \pm 0.67$ & $0.32 \pm 0.01$ & $0.12 \pm 0.01$ \\
\hline JUNE & $26.07 \pm 0.2$ & $7.867 \pm 0.1$ & $753.33 \pm 60.3$ & $570.20 \pm 25.83$ & $8.45 \pm 0.2$ & $3.76 \pm 0.38$ & $7.78 \pm 0.12$ & $0.38 \pm 0.03$ & $0.18 \pm 0.02$ \\
\hline JULY & $25.76 \pm 0.6$ & $6.477 \pm 0.2$ & $650.00 \pm 17.3$ & $466.83 \pm 29.01$ & $10.70 \pm 0.2$ & $5.23 \pm 0.09$ & $7.23 \pm 0.15$ & $0.48 \pm 0.04$ & $0.19 \pm 0.02$ \\
\hline AUGUST & $24.49 \pm 0.9$ & $6.843 \pm 0.1$ & $353.33 \pm 15.3$ & $264.33 \pm 8.37$ & $10.93 \pm 0.1$ & $6.79 \pm 0.51$ & $6.40 \pm 0.10$ & $0.55 \pm 0.02$ & $0.22 \pm 0.01$ \\
\hline SEPTEMBER & $24.42 \pm 0.2$ & $6.407 \pm 0.2$ & $396.67 \pm 15.3$ & $283.34 \pm 3.20$ & $9.45 \pm 0.2$ & $6.63 \pm 0.23$ & $5.55 \pm 0.18$ & $0.51 \pm 0.03$ & $0.22 \pm 0.03$ \\
\hline OCTOBER & $24.49 \pm 0.9$ & $6.843 \pm 0.1$ & $353.33 \pm 15.3$ & $264.33 \pm 8.37$ & $9.75 \pm 0.1$ & $6.79 \pm 0.51$ & $6.40 \pm 0.10$ & $0.55 \pm 0.01$ & $0.22 \pm 0.01$ \\
\hline
\end{tabular}

Values are Mean \pm Standard Deviation.

Table 2: Pearson Correlation Coefficient Between Zooplankton and Physico-Chemical Prameters of Wasai Reservoir (March-October 2018)

\begin{tabular}{|c|c|c|c|c|c|c|c|c|c|c|}
\hline 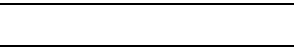 & TEMP. & $\mathrm{pH}$ & EC & TDS & DO & $\mathrm{BOD}_{5}$ & Transparency & Nitrate & Phosphate & Zooplankton \\
\hline Temp. $\left({ }^{\circ} \mathrm{C}\right)$ & 1.00 & & & & & & & & & \\
\hline $\mathrm{pH}$ & $0.79 *$ & 1.00 & & & & & & & & \\
\hline $\mathrm{EC}(\mu \mathrm{S} / \mathrm{cm})$ & $0.84 *$ & $0.9 *$ & 1.00 & & & & & & & \\
\hline TDS (mg/L) & $0.82 *$ & $0.93 *$ & $0.97 *$ & 1.00 & & & & & & \\
\hline $\mathrm{DO}(\mathrm{mg} / \mathrm{L})$ & -0.78 & -0.63 & -0.74 & -0.72 & 1.00 & & & & & \\
\hline $\mathrm{BOD}_{5}(\mathrm{Mg} / \mathrm{L})$ & -0.81 & -0.89 & -0.93 & -0.95 & $0.83^{*}$ & 1.00 & & & & \\
\hline Transparency $(\mathrm{cm})$ & $0.91^{*}$ & $0.79 *$ & $0.79 *$ & $0.81 *$ & -0.81 & -0.88 & 1.00 & & & \\
\hline Nitrate $(\mathrm{mg} / \mathrm{L})$ & -0.79 & -0.79 & -0.84 & -0.79 & $0.73^{*}$ & $0.75^{*}$ & -0.72 & 1.00 & & \\
\hline Phosphate(mg/L) & -0.84 & -0.82 & -0.84 & -0.82 & $0.72 *$ & $0.79 *$ & -0.82 & $0.95 *$ & 1.00 & \\
\hline Zooplankton & $0.722 *$ & $0.62 *$ & $0.64 *$ & $0.67 *$ & -0.73 & -0.78 & $0.84 *$ & -0.61 & -0.73 & 1.00 \\
\hline
\end{tabular}

Correlation is Significant at $\mathrm{P}<0.05$, Correlation Coefficient with * are highly significant at $\mathrm{P}<0.001$.

The Zooplankton phyla identified and their mean monthly value from wasai reservoir are presented in Table 3 and 4. They include: Rotifers, Copepod and Cladocera, with a total of thirteen (13) species. The copepod observed throughout the study time was represented by cyclopoid sp. calanoid sp. and copepod Nauplii (Table 3). The mean monthly diversity of copepod was highest in May (37.67 \pm 5.20$)$ and lowest in October (8.88 \pm 0.39$)$ (Table 4). The Rotifers were represented by five species which include Brachionid caudatus, Brachionid calyciflorus, Brachionid plicatilis, Keratella quadrata and Rotaria neptunia(Table 3).
The mean monthly diversity and distribution of Rotifers revealed highest density in March $(2.93 \pm 0.61)$ and lowest in June $(0.80 \pm 1.06)$ (Table4). Cladocerans were represented by five different species which are Macrothricidae, Leptodora kindtii, Daphnia sp. Bosmind sp.and Sidid sp.(Table 3). Cladocera showed highest mean occurrence during the month of April $(3.40 \pm 1.97)$ and lowest mean occurrence during the month of June and October $(0.27 \pm 0.46$ and $0.27 \pm 0.23$ ) respectively (Table 3 ). 
Table 3: Total Number of Zooplankton Species Observed in Wasai Reservoir (March-October 2018)

\begin{tabular}{llc}
\hline zooplankton Taxa & No. Of organisms & \% frequency \\
\hline Copepoda & & \\
Cyclopoid sp. & 412 & 24.30 \\
Copepode nauplii & 378 & 22.75 \\
Calanoid sp. & 461 & 27.75 \\
Rotifera & & \\
Brachionid caudatus & 100 & 6.02 \\
Brachionid calyciflorus & 93 & 5.59 \\
Keratella quadrata & 32 & 1.92 \\
Brachionid plicatilis & 8 & 0.48 \\
Rotaria neptunia & 4 & 0.24 \\
Cladocera & & \\
Macrothricidae & 14 & 0.48 \\
Leptodora kindtii & 23 & 1.38 \\
Daphnia sp. & 72 & 4.33 \\
Bosmina sp. & 62 & 3.73 \\
Sididae sp. & 2 & 0.12 \\
TOTAL & 1661 & 100 \\
\hline
\end{tabular}

Table 4: Monthly Mean Value of Zooplankton Population in Wasai Reservoir (March-October 2018)

\begin{tabular}{llll}
\hline MONTH & ROTIFERA & COPEPODA & CLADOCERA \\
\hline MARCH & $2.93 \pm 0.61$ & $16.78 \pm 1.26$ & $1.87 \pm 1.41$ \\
APRIL & $2.87 \pm 0.95$ & $29.77 \pm 7.85$ & $3.40 \pm 1.97$ \\
MAY & $2.13 \pm 0.83$ & $37.67 \pm 5.20$ & $2.13 \pm 1.01$ \\
JUNE & $0.80 \pm 1.06$ & $14.78 \pm 3.09$ & $0.27 \pm 0.46$ \\
JULY & $2.67 \pm 0.61$ & $10.66 \pm 0.58$ & $1.60 \pm 0.69$ \\
AUGUST & $1.47 \pm 0.58$ & $10.67 \pm 1.53$ & $0.80 \pm 1.06$ \\
SEPTEMBER & $2.00 \pm 0.40$ & $9.77 \pm 1.01$ & $1.20 \pm 0.40$ \\
OCTOBER & $1.07 \pm 0.61$ & $8.88 \pm 0.39$ & $0.27 \pm 0.23$ \\
\hline
\end{tabular}

\section{DISCUSSION}

The low water temperature recorded in September might be due to the characteristics of rainy season between July to first week of October while the high water temperature in May was due to characteristics of hot weather in north western state of Nigeria, Kano state inclusive. This range of temperature variation is in line with the findings of Ibrahim and Nafi' u (2017) in Thomas Reservoir Danbatta. The result also agreed with the finding of Abubakar and Abdullahi (2015) in Wasai Reservoir which recorded a temperature range of $23.9-25.3^{\circ} \mathrm{C}$. The $\mathrm{pH}$ is an important water quality parameter used in evaluating the acid-base balance in water bodies. Thus, any variation beyond acceptable range could be fatal to aquatic organisms' plankton inclusive. The result observed in Wasai Reservoir fall within the acceptable limit of 6-9 recommended by NESREA (2007). The result is in trend with the finding of
Haruna (2003) which reported that the condusive surface water $\mathrm{pH}$ for zooplankton diversity and distribution is within the range of 6.6-9.3. The higher electrical conductivity observed in April may be attributed to the intensive irrigation farming because of fertilizer application and constant fishing activities that take place during dry season and such activities are lacking in wet season due to increase in water level as a result of rain. This agrees with the observation made by Sebastainet al. (2004) that the higher the ionic concentration in water the greater the electrical conductivity. TDS are inorganic compounds that are found in water such as salt, heavy metals and some traces of organic compounds dissolved in water. Haruna (2003) reported that high values of TDS may lead to changes in water taste. TDS was in April and lower in August and October. The high value of TDS observed in April might be as a result of nonmoving behavior of water in the Reservoir. 
This trend of TDS variation is in tandem with the finding of Ibrahim and Nafi' $u$ (2015) in Thomas Reservoir. The result also falls within the maximum limit of $600 \mathrm{mg} / \mathrm{L}$ set by NESREA (2007). Dissolved oxygen is one of the most important parameters that indicate water purity. It is essential in maintaining a variety of forms of biological life in water. The DO was high in August and low in May. The high value of dissolved oxygen observed in August might be due to the characteristics of rain and a lot of mixing that takes place regularly, while low dissolved oxygen recorded in May was due to high temperature and hot weather in Kano. This result was in agreement with the value of DO observed by Ibrahim and Nafi' u (2017) in Thomas Reservoir. The result contradicts with the finding of Abubakar and Abdullahi (2015) in Jakara Reservoir, where DO value of $3.3 \mathrm{mg} / \mathrm{L}$ was recorded in rainy season and $2.5 \mathrm{mg} / \mathrm{L}$ in dry season respectively. Biochemical oxygen demand is a measurement of the amount of dissolved oxygen that is used by aerobic microorganisms when decomposing organic matter in water. The low BOD value obtained in May was due to high level of decomposition by aerobic microorganisms. The result of this study agreed with the finding of Abubakar and Abdullahi (2015) that studied flora composition of phytoplankton as bioindicators of water quality in Wasai Reservoir, Kano. They reported that BOD was lower in the dry season than in rainy season during period of oxygen consumption by decomposers (bacteria and fungi) on biogenic materials. Transparency was low in September and high in May. The highest value of transparency recorded in May might be as result of low level of turbidity while the low secchi disc transparency in September might be as a result of increase in water level as a result of rain. This result is in line with the findings of Ibrahim (2009) in Challawa River. The concentration of nutrient in water body is strongly influenced by the nature of the sediment. The value of nitrate obtained from this study was below WHO and FEPA tolerance limit of $45 \mathrm{mg} / \mathrm{L}$ for drinking water (Mahreet al., 2007), but in agreement with the findings of Abubakar and Abdullahi (2015) in Jakara Reservoir. Wetzel (2001) reported that the rate of phosphorus released in to water body can be double when the sediments are frequently distributed. The phosphate concentration was low in March and high in September. The highest value of phosphate obtained in September could be attributed to the rainy season's farming activities and concentration of fertilizer due to water runoff from farms. The result was however not in agreement with the finding of Mohammad and Saminu (2015) that studied the effect of physico-chemical factors and seasonal dynamics of zooplankton in Nguru Lake.

Thirteen (13) species of zooplankton were identifiedin this study the zooplankton population was dominated by copepod followed by rotifers while cladoceran has least occurrence. The zooplankton species identified in this study had its highest occurrence during the month of MarchJune and lowest in the month of July-October. Their abundance in March-June could be due to the availability of nutrient (phytoplankton) and relatively favorable temperature, as reported by Kamat (2000) water temperature ranging between $13.5-32^{\circ} \mathrm{C}$ is suitable for the development of planktonic organisms. Their low number in rainy season could be attributed to non-availability of nutrient (phytoplankton) as a result of low transparency level among other factors that strongly limit light penetration and thus photosynthesis. The result of this study was in agreement with the finding of Ibrahim (2009) in Challawa River.

\section{CONCLUSION}

It is concluded that the physico-chemical water condition of Wasai Reservoir (temperature, $\mathrm{pH}$, EC, TDS,DO, BOD, TransparencyNitrate and Phosphate) determined from this study is within the normal range, it range from $24.4-29.1^{\circ} \mathrm{C}, 6.4-$

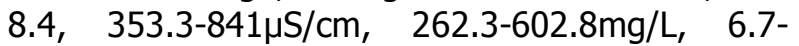
$10.93 \mathrm{mg} / \mathrm{L}, \quad 2.7-6.7 \mathrm{mg} / \mathrm{L}, \quad 5.5-12.3 \mathrm{~cm}, \quad 0.12-$ $0.55 \mathrm{mg} / \mathrm{L}$ and $0.08-0.22 \mathrm{mg} / \mathrm{L}$ respectively.

Evidence from this study also shows that in some parameters such as temperature, $\mathrm{pH}, \mathrm{EC}$, TDS and Transparency revealed strong positive correlation with zooplankton organisms observed while DO, BOD, Nitrate and Phosphate revealed negative correlation with zooplankton organisms. 


\section{REFERENCES}

Abubakar, A. and Abdullahi, B.A (2015): Flora Composition of Phytoplankton as Bioindicators of water quality in Jakara dam, Kano State, Nigeria. Bayero Journal of Pure and Applied Sciences, 8(2): 145 - 155 http://dx.doi.org/10.4314/bajopas.v8i2.25

Bennett, D.P. and Daved, A.H. (1974): River pollution studies, Liverpool university press.

Boyd, C.E and Frobish, L.Y. (1998): Water Quality for Ponds Aquaculture. Birmingham Publishing Co., Birminghsm, UK. 5-90.

Brown, A. L. (1987). Freshwater Ecology. Heinemann Educational Books Ltd., London.

Bryan, J.R. (1976).A wrinkler Procedure for Oxygen Measurement. Journal of Experimental Microbial Ecology, 42 (2-4): 23-24.

Duwa, M.R. and Oyeyi T.T. (2009): The role of Jakara Dam in the Transmission of Schistosomiasis: Journal of Pure and Applied Sciences. 2 (1) 58-63.

Haruna, B.A. (2003). Aquaculture in the tropics:theory and practices. Al-Hassan Pub. Pp: 21-254

Hart, D., Stone, L. and Berman, T. (2000). Seasonal dynamics of the Lake Kinneret food web: the importance of the microbial loop. Limnology and Oceanography. 45: 350-361.

Hashemzadeh, Farshad and Venkataramana. G.V.(2012).Impact of Physico-Chemical Parameters of Water on Zooplankton Diversity in Nanjan gud Industrial Area, India. International Research Journal of Environment Sciences 1(4), 37-42.

Ibrahim, S. (2009): A survey of zooplankton Diversity of Challawa River, Kano And Evaluation of some of it Physico-Chemical Condition. Depatment of Biological Sciences, Bayero University. Bayero Journal of Pure and Applied Sciences, 2(1): 19-26

Ibrahim, S and Nafi'u, S. A. (2017).Phytoplankton as Indicators of Water Quality in Thomas Dam, Dambatta, Kano State, Nigeria.Dutse Journal of Pure and Applied Sciences (DUJOPAS) Vol. 3 No. 1.

Kamat M.D. (2000). Ecological notes on Kohlapu, J.Environ. Biol.Sci, 8, 47-54.

Laws, E.A. Bienfang, P.K. Ziemann, D.A. and Conquest L.D. (1988). Phytoplankton population dynamics and the fate of production during the spring bloom in Auke Bay, Alaska. Limnology and Oceanography. 33: 57-65.

Lynne M. and Witty, (2004). Practical Guide to Identifying freshwater crustacean
zooplankton.(Aquatic

Invertebrate Taxonomist, cooperative freshwater ecology unit $2^{\text {nd }}$ edition).

Mahre, M.Y., Akan J.C., Moses, E.A. and Ogugbuaja V.O. (2007): Pollution Indicators in river Kaduna, Kaduna state, Nigeria. Trends in Applied Sciences Research, 2:304-311.

Mohammad, M.A. and Saminu, M.Y. (2012): A Water Quality and Phytoplankton of Salanta River Kano, Nigeria: .Journal of Biological Science and Bioconservation 4: 2277-0143.

Mustapha, M.K. (2009). Zooplankton assemblage of Oyun Reservoir, Offa, Nigeria Rev. Biol. Trop., 57, (Issue 4), pp: 1027-1047.

NESREA (2007): National Environmental Standard and Regulation Enforcement Agency (Effluent limitation). Regulation of 2007 National Environmental Standard and Regulation Enforcement Agency Lagos, Nigeria.Fef. No. S.18

Omudu E.A. and Odeh P. (2006). A survey of zooplankton and macroinvertebrates of Agi Stream in Ojo Benue State, and their implications for transmission of endemic diseases, Biological and Environmental Sciences Journal for the Tropics, 3(2): 1017.

Sandercock, G.A. Vancouver, B.C. and Scudder, G.G.E. (1994). An Introduction and Key To The Freshwater Calanoid Copepods (Crustacea) of British Columbia.Universityof British Columbia.

SAS. (1985): Statistical Analysis System Institute Inc., SAS/STAT User's Guide Version. 5th edn., Vol. 1, Cary, NC.

Sebastain, F., Joseepht, H. and Alvaro, M. (2004): The Effect of Nitrates Concentration on Conductivity in four Water Sources. Colegio Franklin Delano Roosevelt.4-8.

Sivakumar, K. and Karuppasamy, R. (2008).Factors affectingproductivity of phytoplankton in a reservoir ofTamilnadu, India. Am. Eurasian J. Botany, 1(3): 99-103.

SHEIL, R.J. (1995). A Guide to Identification of Rotifers, Cladocerans and Copepods from Australian inland Water.Murray-Darling freshwater Research Center Identification guide No. 3

Wetzel, R.G. (2001): Limnology, Lake and River Ecosystems (3rd edn) Academic Press. San Francisco

WRECA (1974): Hydrobiological Survey of North East Kano State Planning Programed 